\title{
Cloning and characterization of a 9-lipoxygenase gene induced by pathogen attack from Nicotiana benthamiana for biotechnological application
}

\author{
Fong-Chin Huang and Wilfried Schwab*
}

\begin{abstract}
Background: Plant lipoxygenases (LOXs) have been proposed to form biologically active compounds both during normal developmental stages such as germination or growth as well as during responses to environmental stress such as wounding or pathogen attack. In our previous study, we found that enzyme activity of endogenous 9-LOX in Nicotiana benthamiana was highly induced by agroinfiltration using a tobacco mosaic virus (TMV) based vector system.

Results: A LOX gene which is expressed after treatment of the viral vectors was isolated from Nicotiana benthamiana. As the encoded LOX has a high amino acid identity to other 9-LOX proteins, the gene was named as Nb-9-LOX. It was heterologously expressed in yeast cells and its enzymatic activity was characterized. The yeast cells expressed large quantities of stable 9-LOX $\left(0.9 \mathrm{U} \mathrm{ml}^{-1}\right.$ cell cultures) which can oxygenate linoleic acid resulting

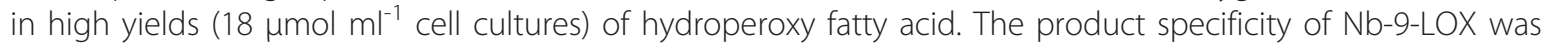
examined by incubation of linoleic acid and Nb-9-LOX in combination with a 13-hydroperoxide lyase from watermelon (Cl-13-HPL) or a 9/13-hydroperoxide lyase from melon (Cm-9/13-HPL) and by LC-MS analysis. The result showed that Nb-9-LOX possesses both 9- and 13-LOX specificity, with high predominance for the 9-LOX function. The combination of recombinant Nb-9-LOX and recombinant Cm-9/13-HPL produced large amounts of $\mathrm{C}_{9^{-}}$ aldehydes $\left(3.3 \mu \mathrm{mol} \mathrm{mg} \mathrm{mg}^{-1}\right.$ crude protein). The yield of $\mathrm{C}_{9}$-aldehydes from linoleic acid was $64 \%$.

Conclusion: The yeast expressed $\mathrm{Nb}$-9-LOX can be used to produce $C_{9}$-aldehydes on a large scale in combination with a HPL gene with 9-HPL function, or to effectively produce 9-hydroxy-10(E),12(Z)-octadecadienoic acid in a biocatalytic process in combination with cysteine as a mild reducing agent.
\end{abstract}

Keywords: Lipoxygenase hydroperoxide lyase, viral vector system, $C_{9}$-aldehyde, 9-hydroxy-10(E), 12(Z)-octadecadienoic acid (9-HOD), Nicotiana benthamiana

\section{Background}

Lipoxygenases (LOXs) are nonheme iron-containing enzymes that catalyze the dioxygenation of fatty acids with a 1,4-pentadiene structure and are ubiquitous among eukaryotes [1]. Hydroperoxidation products derived from LOX enzymes can be further converted into other oxylipins through the activity of diverse enzymes downstream in the pathways, including hydroperoxide lyase (HPL), allene oxide synthase, divinyl ether synthase, epoxy alcohol synthase, and peroxygenase [2,3].

\footnotetext{
* Correspondence: schwab@wzw.tum.de

Technische Universität München, Biotechnology of Natural Products, LieselBeckmann-Str. 1, D-85354 Freising, Germany
}

These oxylipins include jasmonates, octadecanoids, 6and 9-carbon aldehydes, oxoacids and divinyl ether fatty acids which are involved in plant defence, senescence, seed germination, plant growth and development.

LOX enzymes can be grouped into two types according to their regiospecificity: 9-LOX, which specifically forms 9-hydroperoxy fatty acid, and 13-LOX, which predominantly catalyzes the formation of 13-hydroperoxy fatty acid. Some LOX enzymes can produce both 9- and 13-hydroperoxy products. Soybeans LOX1, 2, and 3 have different $\mathrm{pH}$ optima and different product specificities [4]. LOX1 has a pH optimum of 9.0, producing (13S)-hydroperoxy-octadecadienoic acid (HPOD) as the

\section{() Biomed Central}


major product from linoleic acid. LOX2 with a $\mathrm{pH}$ optimum of 6.1 forms almost equal proportions of 9- and 13-HPODs, whereas LOX3 with a $\mathrm{pH}$ optimum of 6.5 produces approximately $65 \%$ and $35 \% 9$ - and 13 HPODs, respectively [4].

Plant LOXs have been proposed to form biologically active compounds both during normal developmental stages such as germination or growth as well as during responses to environmental stress such as wounding or pathogen attack [1]. Recently, it has been shown that 9LOX products in plants play an important role in defence responses. In plants, correlative data suggest that 9-LOXs are crucial for lipid peroxidation during the hypersensitive response [5-7]. Pathogen-induced 9LOX transcript accumulation has been reported in a number of plants, e.g. in tobacco after infection with Phytophthora parasitica var. nicotianae [8], in potato infected by Phytophthora infestans [9], in almond infected by Aspergillus carbonarius [10], and in pepper infected by Xanthomonas campestris pv vesicatoria [11]. Recently, we also found that endogenous 9-LOX activity in $N$. benthamiana was highly induced by agroinfiltration [12]. The strong involvement of 9-LOX in the defence of plants has been demonstrated using antisense strategy or virus-induced gene silencing $[8,11]$. In addition to having a role in defence responses to pathogens, 9-LOXs also are implicated in plant developmental processes. A specific 9- $L O X$ gene is transiently induced during potato tuber growth, and its antisense suppression resulted in reduced tuber size [13]. In Arabidopsis, 9$L O X$ has been reported to play an important role in late root development [14]. In monocots, maize 9-LOX $(Z m L O X 3)$ has been suggested to be highly involved in regulation of development and to act as a susceptibility factor $[15,16]$.

LOXs also have a role in the production of volatile molecules that can positively or negatively influence the flavour and aroma of many plant products [17]. Volatile $\mathrm{C}_{6^{-}}$and $\mathrm{C}_{9}$-aldehydes, such as hexanal, (3Z)- and $(2 E)$ hexenal, (3Z)- and (2E)-nonenal, as well as $(3 Z, 6 Z)$ - and $(2 E, 6 Z)$-nonadienal are products of unsaturated fatty acids metabolized by LOX and HPL, and are important components of the aroma and flavour of fruits and vegetables. The sequence starts with the oxygenation of linoleic acid and linolenic acid by 9- or 13-LOX to form 9or 13-hydroperoxy-octadecadienoic/octadecatrienoic acids (HPOD/T), respectively. The 13-hydroperoxy fatty acids can subsequently be cleaved by 13 -HPL into 12 oxo-(9Z)-dodecenoic acid and hexanal or (3Z)-hexenal, whereas the 9-hydroperoxy fatty acids can be cleaved by 9-HPL into 9-oxononanoic acid and (3Z)-nonenal or $(3 Z, 6 Z)$-nonadienal $[18,19]$. The $(3 Z)$-aldehydes isomerize either spontaneously or enzymatically catalyzed to their $(2 E)$-enal isomers and can be reduced to their corresponding alcohols by alcohol dehydrogenase. Due to their organoleptic characteristics, $\mathrm{C}_{6}$-aldehydes and alcohols are often called green notes and are widely used as flavours in foods and beverages [20,21]. Besides, $(2 E)$-nonenal is considered to be the aged flavour in cereal products, including rice and beer [22,23] whereas $(2 E, 6 Z)$-nonadienal was found to have the greatest fresh cucumber odour impact $[24,25]$. The isomer (3Z)-nonenal is used for fresh, tropical, melon notes [21]. (2E)Nonenal and (2Z)-nonenal were also identified in Cheddar cheese and were found to play an important role on the odour [26]. Due to their anti-microbial activities, $(2 E)$-hexenal, $(2 E)$-nonenal and $(2 E, 6 Z)$-nonadienal are potential candidates in the control of main mite species in food and feed commodities [27]. These compounds can be extracted from plants or synthesized. However, chemical synthesis is not favoured because consumers have a strong preference for natural food additives $[28,29]$. In addition, extraction is very expensive because of the low abundance of these short-chain aldehydes and alcohols in plants and cannot meet the increasing market demand for natural flavours. For example, the natural green notes market is estimated at 5-10 ton year $^{-1}$ and US\$ $3000 \mathrm{~kg}^{-1}$ [30]. Therefore, development of a biocatalytic process is required to produce these compounds on a large scale.

Hydroxy fatty acids (HFAs) are multifunctional molecules that have a variety of applications. HFAs and their derivatives are used in cosmetics, paints and coatings, lubricants, and the food industry. HFAs are also encountered in nature as cyclic esters known as lactones which are used in perfumes and as flavour components in food [31,32]. The most important lactone for flavour application with a market volume of several hundred tons per year is $\gamma$-decalactone which is transformed from ricinoleic acid (12-hydroxyoctadec-9-enoic acid) $[28,33]$. Some other examples of HFAs used as precursors of flavour compounds are 13-hydroxy-, and 10hydroxyoctadecanoic acid and 14-hydroxynonadecanoic acid, from which $\delta$-decanolide, $\gamma$-dodecanolide, and $\gamma$ nonanolide are generated, respectively [34]. Besides, fatty acids with multiple functional groups can serve as monomers for polymerization and to produce other useful compounds, such as surface active agents $[35,36]$. Fatty acid hydroperoxides, obtained from LOX action, can act as precursors for further transformation by chemical reactions for the production of HFAs [37,38]. A number of reagents have been used to reduce hydroperoxides into the corresponding hydroxides, such as $\mathrm{SnCl}_{2}, \mathrm{NaBH}_{4}, \mathrm{KOH}$, and cysteine [37-39].

We previously demonstrated that 9-LOX activity is highly induced in tobacco cells after treating with viral vectors [12]. In this study, we have isolated the 9-LOX gene from infiltrated $N$. benthamiana leaves which 
displayed high 9-LOX activity, and expressed it in yeast cells. The biochemical function of Nb-9-LOX was characterized. The potential biotechnological applications of 9-LOX were described.

\section{Results}

Expression of the $\mathrm{Nb}-9-\mathrm{LOX}$ gene is induced by pathogen attack but not by wounding

It has been reported that the expression of $L O X$ gene(s) is induced by wounding and pathogen infection $[5,7,40]$. In our previous study, we found that 9-LOX enzyme activity in $N$. benthamiana was highly induced by agroinfiltration using a tobacco mosaic virus (TMV) based vector system $[12,41,42]$. In order to find out the best material for isolation of the 9-LOX gene, $N$. benthamiana leaves were infiltrated with a series of mixtures of viral provectors (detailed description see Experimental procedures): 1) 3'-provector; 2) 3'-provector and integrase provector; 3) 3'-provector and 5'- provector; 4) 3'-provector, 5'-provector and integrase provector. The infiltrated leaves were harvested after 12 days and analyzed. The expression levels of 9-LOX were examined in treated $N$. benthamiana leaves and untreated leaves by real-time PCR using an 18S-26S interspacer gene as an internal control for normalization. As expected, all leaves which were treated with bacterial suspensions showed a much higher expression level of 9-LOX than untreated leaves (column $C$ ) and leaves infiltrated with buffer (column B) (28-180 times) (Figure 1A). Moreover, the expression of 9-LOX was even more induced, when $N$. benthamiana leaves were co-infiltrated with 3'-provector and 5'-provector together with the integrase provector (column 4). These results revealed that the expression of endogenous 9$L O X$ gene in tobacco was more strongly induced by a fully functional RNA replicon. LOX enzyme activities were also monitored in control and infected leaves by LC-MS (Figure 1B). The result showed that 9-HPOD was the main product (Figure 1C). A very low enzymatic activity was detected in the untreated leaves (column C) and leaves infiltrated with buffer (column B). The 9LOX activities in all infected leaves were significantly higher than those in control leaves. The leaf treated with 3'-provector and 5'-provector together with the integrase provector displayed the highest 9-LOX activity. This result coincided with that of real-time PCR analysis.

The effect of wounding on $N b-9-L O X$ gene expression was also tested. Leaves of $N$. benthamiana were wounded by infiltration with buffer (detailed description see Experimental procedures). The expression level of $N b-9-L O X$ was analyzed in $N$. benthamiana leaves at different times after wounding by real-time PCR. As a

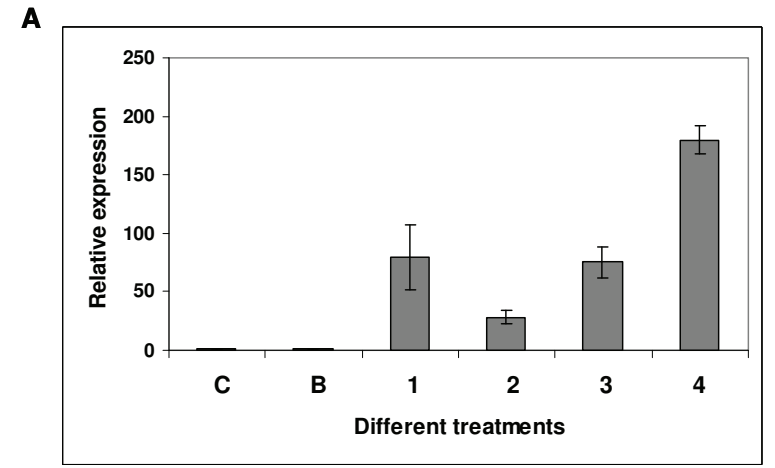

B

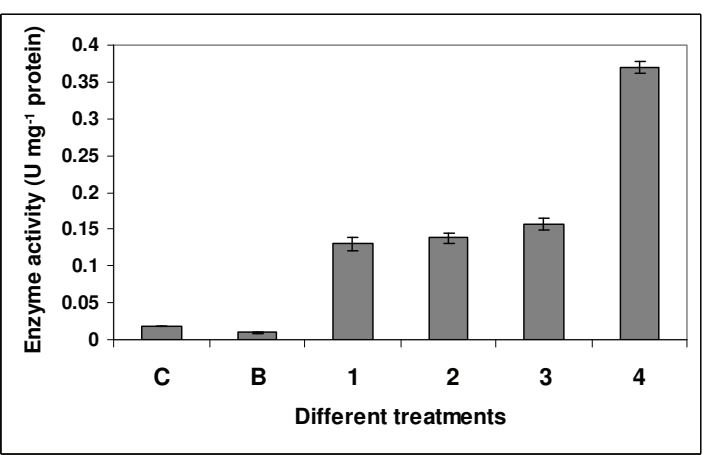

C

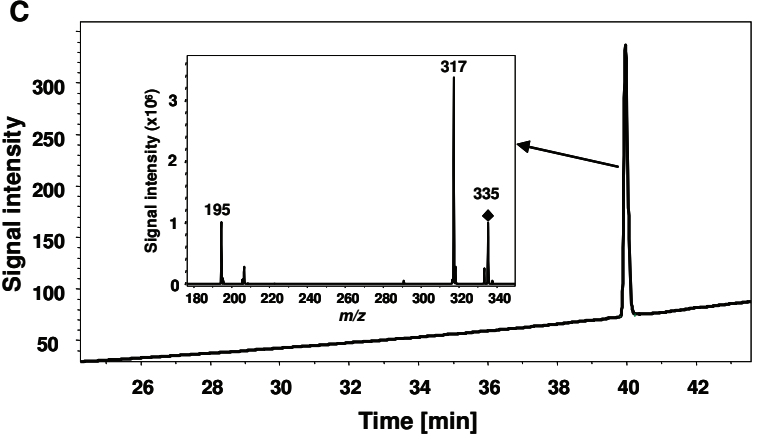

Figure 1 Analysis of Nb-9-LOX gene expression and LOX activity in $N$. benthamiana plants treated with agrobacterial suspensions containing different mixtures of viral provectors: 1) 3'-provector; 2) 3'-provector and integrase provector; 3) 5'provector and integrase provector; 4) 3'-provector, 5'-provector and integrase provector; C) untreated N. benthamiana; B) leaf infiltrated with buffer. Leaves were harvested 12 days after infiltration. (A) Quantitative real-time RT-PCR analysis was performed using Nb-9LOX and 18S-26S interspacer gene specific primers, the latter used as an internal control for normalization. Values of Nb-9-LOX gene expression are means \pm SEM of three different evaluations carried out with two sets of CDNAs. (B) LOX activities. LOX activity was measured at $\mathrm{pH} 7.0$ using linoleic acid as a substrate. The reaction products were analyzed by LC-MS. Concentrations of product (9HPOD) were determined using a standard curve calculated from various known concentrations of 9-HPOD against the UV peak areas which were recorded at $234 \mathrm{~nm}$ by LC-MS. Each bar represents the mean and standard error of two replicates. (C) LC-MS analysis of product formed from the reaction containing crude protein extracts of infiltrated tobacco leaf and linoleic acid. 9-HPOD ( $\mathrm{m} / \mathrm{z} 335 \rightarrow 195$, positive mode) was found to be the main product. 
result, gene expression of $N b-9-L O X$ did not show any significant difference after wounding compared to that after infection with the viral vectors (Figure 2). Furthermore, LOX activities were measured in untreated leaf, and leaves at different times after wounding by LC-MS. As expected, 9-LOX activity did not show any clear difference between untreated and wounded leaves (data not shown).

\section{Cloning and heterologous expression of $\mathrm{Nb}-9-\mathrm{LOX}$ in yeast}

For cloning of 9-LOX gene from $N$. benthamiana, infiltrated leaves with a fully functional RNA replicon which displayed a high LOX activity were chosen according to the induction profiles as described above. The fulllength cDNA of 9-LOX gene was isolated using RT-PCR and a set of primers designed on the basis of a tobacco 9-LOX gene (Genbank accession number X84040). The cDNA sequence which we obtained from $N$. benthamiana encoded a protein of 862 amino acids with a calculated molecular mass of $97.4 \mathrm{kDa}$ and a predicted pI of 5.52. N. benthamiana LOX shows $96 \%$ amino acid identity with a previously isolated tobacco 9-LOX [43], and is $87 \%$ and $84 \%$ identical to a tomato LOX (Genbank accession number AAG21691) and potato tuber LOX (Genbank accession number AAB67865), respectively. We designated this clone as $N b-9-L O X$.

$\mathrm{Nb}-9-L O X$ was cloned into a pYES2 vector for expression in yeast to characterize the enzymatic activity of the encoded protein. The crude protein extracts from yeast cells which were harvested at $0,4,8$, and 24 hours after galactose induction were separated on a $12 \%$ SDS-

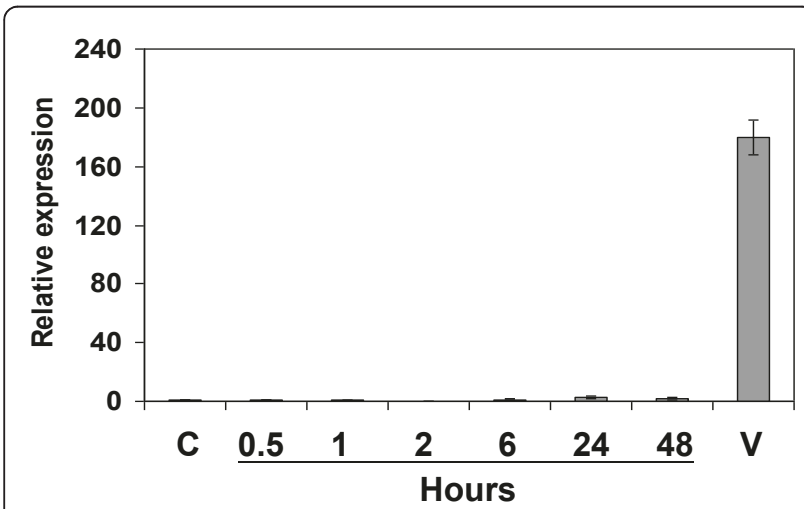

Figure 2 The effect of wounding on Nb-9-LOX gene expression. Leaves of $N$. benthamiana were infiltrated with buffer and were harvested at $30 \mathrm{~min}, 1 \mathrm{~h}, 2 \mathrm{~h}, 6 \mathrm{~h}, 24 \mathrm{~h}$, and $48 \mathrm{~h}$ after wounding treatment. Quantitative real-time RT-PCR analysis was performed using Nb-9-LOX and 18S-26S interspacer gene specific primers, the latter used as internal control for normalization. Values are means \pm SEM of three different evaluations carried out with two sets of cDNAs. Column C, untreated N. benthamiana; column V, tobacco leaf treated with TMV vectors. gel. Nb-9-LOX could already be observed on the SDSgel 4 hours after induction (Figure 3A). Heterologously expressed Nb-9-LOX was identified by Western blot analysis using soybean LOX antibody. The results confirmed that $\mathrm{Nb}-9$-LOX was already expressed 4 hours after induction, and its highest level was observed 24 hours after induction (Figure 3B). LOX activity was measured at room temperature by the formation of the conjugated diene at $234 \mathrm{~nm}$. The crude protein extracts from yeast cells which were harvested at 24 hours after induction displayed the highest LOX activity (Figure 4A). Therefore, Nb-9-LOX used for all assays was prepared from yeast cell culture harvested at 24 hours after induction. Under optimal culture condition, about $0.91 \pm 0.13 \mathrm{U}$ LOX activity was obtained from crude protein extracted from $1 \mathrm{ml}$ yeast cell culture. $\mathrm{Nb}$-9-LOX-yeast protein extracts prepared from $1 \mathrm{ml}$ yeast cell culture could convert $18 \mu$ mole of linoleic acid into $17.85 \mu$ mole of 9-HPOD. The transformation yield was $99 \%$ (Table 1).

The enzymatic activity of Nb-9-LOX was analyzed at different $\mathrm{pH}$ values ( $\mathrm{pH} 2-9)$ and temperatures (15-45 C) to find out the optimal catalytic conditions,. The yeast-expressed $\mathrm{Nb}$-9-LOX enzyme has a temperature optimum at $35^{\circ} \mathrm{C}$ with linoleic acid as substrate and a $\mathrm{pH}$ optimum of 6.0 with a reproducible slight reduction

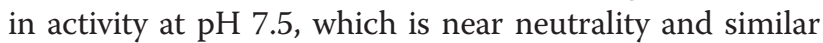
to that of other 9-LOX enzymes (Additional file 1: Figure S1A and S1B). The $K_{m}$ for the substrate linoleic acid was $3.9 \mu \mathrm{M}$ (Additional file 1: Figure S1C and S1D).

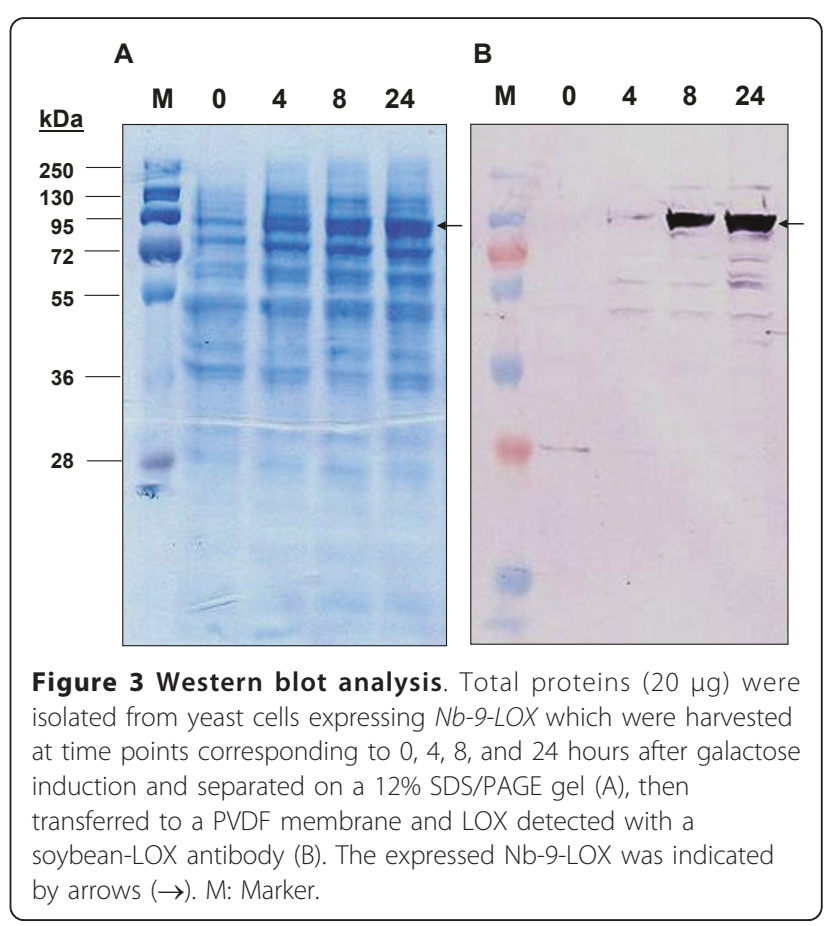


A

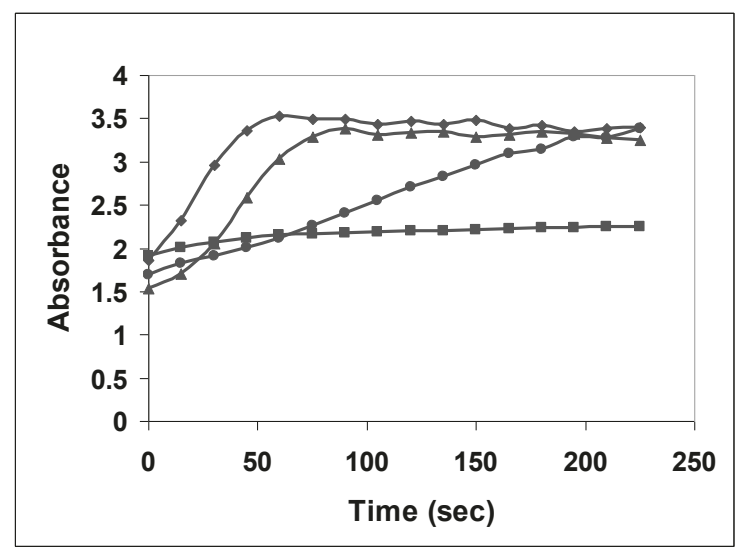

C

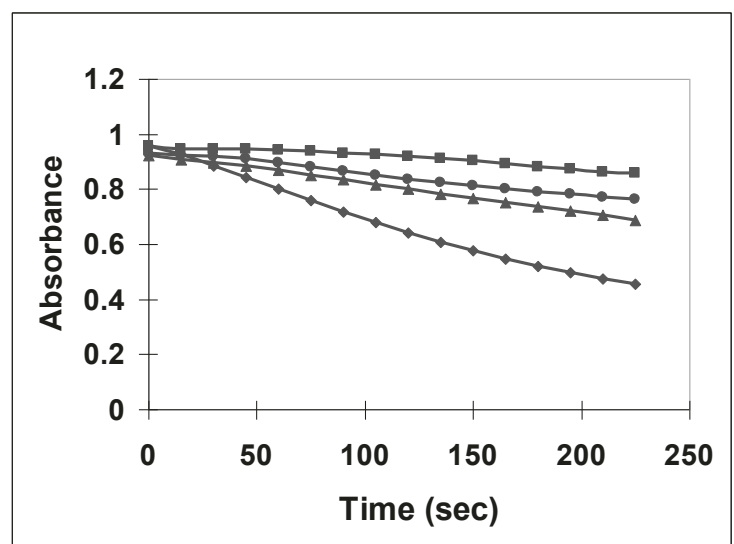

B

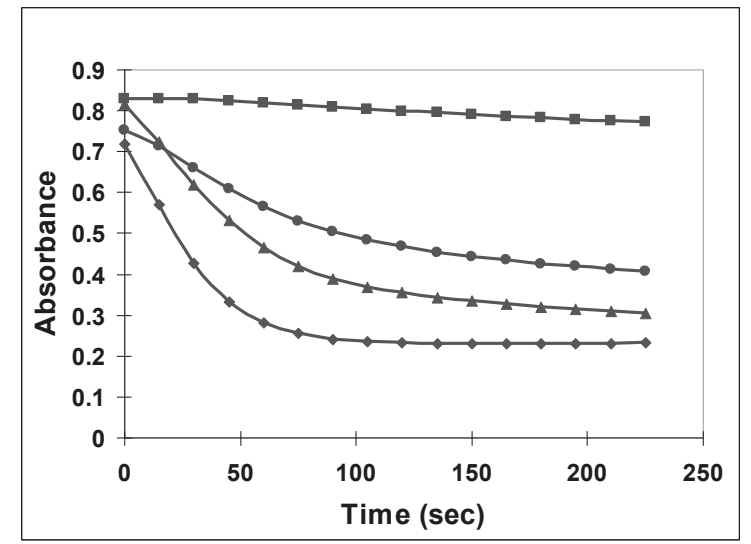

D

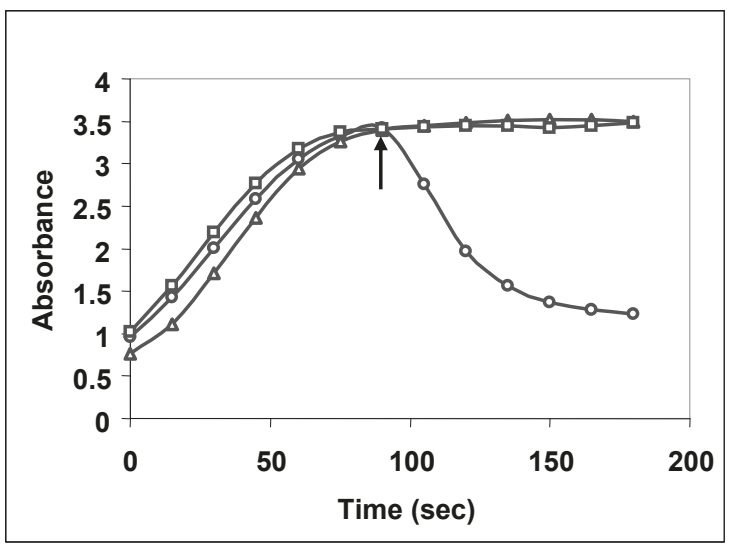

Figure 4 Analysis of LOX and HPL activities at $\mathbf{2 3 4} \mathbf{n m}$ by spectrophotometry. Total proteins were isolated from yeast cells expressing $\mathrm{Nb}$ 9-LOX (A), Cm-9/13-HPL (B), and Cl-13-HPL (C) which were harvested at time points corresponding to $0(-\mathbf{-}-), 4(-\bullet-), 8(-\mathbf{-}-)$, and $24(-\bullet-)$ hours after galactose induction. Nb-9-LOX activity was measured at pH 7.0 using linoleic acid as a substrate, $\mathrm{Cm}-9 / 13-\mathrm{HPL}$ activity was measured at pH 7.0 using 9(S)-HPOD as a substrate, and Cl-13-HPL activity was measured at pH 6.0 using 13(S)-HPOD as a substrate. LOX activity was measured at room temperature by the formation of the conjugated diene at $234 \mathrm{~nm}$, while HPL activity was measured by the decrease of $A_{234}$ due to cleavage of the substrate. (D) Reaction of linoleic acid with yeast cell extract of Nb-9-LOX (- $\triangle-)$, followed by addition of yeast cell extract of Cl-13HPL (-口-) or yeast cell extract of Cm-9/13-HPL (-o-) at 90 seconds (arrow).

Table 1 Effect of substrate concentration on the yield of 9-HPOD from linoleic acid catalyzed by Nb-9-LOX-yeast protein extracts prepared from $1 \mathrm{ml}$ of cell culture in 20 $\min$

\begin{tabular}{lll}
\hline Linoleic acid $(\boldsymbol{\mu m o l})$ & 9-HPOD $(\boldsymbol{\mu m o l})$ & Yield $(\%)$ \\
\hline 12 & $11.8 \pm 0.4$ & 98 \\
15 & $14.4 \pm 0.6$ & 96 \\
18 & $17.9 \pm 1.5$ & 99 \\
24 & $20.2 \pm 3.0$ & 84 \\
30 & $19.7 \pm 0.7$ & 66 \\
\hline
\end{tabular}

The amount of 9-HPOD was determined using a standard curve calculated from various known concentrations of 9-HPOD against the UV peak areas which were recorded at $234 \mathrm{~nm}$ by LC-MS. Each value is the average and standard error of two replicates.
Cloning and heterologous expression of $\mathrm{Cm}-9 / 13-\mathrm{HPL}$ and $\mathrm{Cl}-13-\mathrm{HPL}$ in yeast

For production of $\mathrm{C}_{6}$ - or $\mathrm{C}_{9}$-aldehydes by a coupled LOX-HPL reaction, full-length cDNAs of 13-HPL from watermelon leaves ( $\mathrm{Cl}-13-\mathrm{HPL}$, Genbank accession number AY703450) and 9/13-HPL from melon fruit (Cm-9/ 13-HPL, Genbank accession number AF081955) were isolated using RT-PCR and heterologously expressed in yeast. HPL activity was determined by measuring the decrease of $A_{234}$ due to cleavage of the substrate. HPL activities of both Cm-9/13-HPL and Cl-13-HPL could be detected 4 hours after induction, and for both the highest HPL activity was measured 24 hours after 
induction (Figure 4B and 4C). The activity of Cl-13-HPL was $0.2 \pm 0.01 \mathrm{U} \mathrm{mg}^{-1}$ of protein with $13(S)$-HPOD, while that of $\mathrm{Cm}-9 / 13-\mathrm{HPL}$ was $0.94 \pm 0.03 \mathrm{U} \mathrm{mg}^{-1}$ of protein with $9(S)$-HPOD and $1.06 \pm 0.08 \mathrm{U} \mathrm{mg}^{-1}$ of protein with 13(S)-HPOD. As described in previous studies, Cl-13-HPL has a strong preference for 13-HPODs over 9-HPODs [12,44], and Cm-9/13-HPL has dual activity on both 9- and 13-HPODs [45]. Cm-9/13-HPL cleaves 13-HPOD and 9-HPOD with almost the same efficiency.

\section{Regiospecificity of $\mathrm{Nb}-9$-LOX}

The positional specificity of Nb-9-LOX was determined. At first, Nb-9-LOX was co-assayed with Cm-9/13-HPL or $\mathrm{Cl}-13-\mathrm{HPL}$ and the absorbance at $234 \mathrm{~nm}$ was observed by spectrophotometry. When linoleic acid was incubated with yeast extracts expressing $\mathrm{Nb}-9$-LOX, the absorbance at $234 \mathrm{~nm}$ increased rapidly due to the LOX-catalyzed formation of linoleic acid hydroperoxide. After $90 \mathrm{sec}$, yeast extracts of Cl-13-HPL or Cm-9/13HPL were added to the reaction mixture. An immediate decrease in absorption at $234 \mathrm{~nm}$ (loss of the conjugated diene hydroperoxide) was observed after adding Cm-9/ 13-HPL yeast extracts (Figure 4D). In contrast, the addition of Cl-13-HPL yeast extracts did not alter absorption at $234 \mathrm{~nm}$. This result revealed the regiospecificity of Nb-9-LOX which specifically forms 9-HPOD, a substrate for 9-HPL.

Furthermore the reaction products formed by Nb-9LOX were identified by LC-MS analysis. Ion trace at $\mathrm{m} / \mathrm{z}$ $195\left[\mathrm{C}_{9} \mathrm{H}_{16} \mathrm{O}_{3}+\mathrm{Na}\right]^{+}$was monitored to quantify the production of 9-isomer, whereas for 13-isomer $\mathrm{m} / z 247$ $\left[\mathrm{C}_{13} \mathrm{H}_{20} \mathrm{O}_{3}+\mathrm{Na}\right]^{+}$was looked at. The result showed that 9HPOD was mainly produced when Nb-9-LOX-expressed yeast extracts were incubated with linoleic acid. However, 13-HPOD was not detectable (Additional file 1: Figure $\mathrm{S} 2$ ). Under different $\mathrm{pH}$ conditions, the product profile was not changed (data not shown). These results suggested that Nb-9-LOX is indeed a 9-specific LOX.

\section{Production of $\mathrm{C}_{9}$-aldehyde in a one-pot process}

The one-pot process is a bioprocess in which the LOX and HPL reactions take place simultaneously. To evaluate the short-chain aldehyde forming activity in the combinations of Nb-9-LOX with Cl-13-HPL or Cm-9/ 13-HPL, linoleic acid was added to the reaction solutions containing different yeast cell extracts (Figure 5). Reaction products were analyzed by SPME-GC-MS. Low levels of hexanal $(\mathrm{m} / z \mathrm{82}, 72,56,55)$ (Figure $5 \mathrm{~A}$, peak $1),(3 Z)$-nonenal $(m / z 111,96,84,69,55)$ (Figure $5 \mathrm{~B}$, peak 2), putative (2Z)-nonenal $(\mathrm{m} / z 111,96,83,70,55)$ (Figure $5 B$, peak 3$)$ and $(2 E)$-nonenal $(m / z 111,96,83$, $70,55)$ (Figure $5 \mathrm{~B}$, peak 4 ) were detected, when linoleic acid was incubated with the crude enzyme solution containing Nb-9-LOX in combination with Cl-13-HPL. A low level of hexanal was also detected in the reaction mixture containing $\mathrm{Nb}-9$-LOX in combination with Cm-9/13-HPL. However, a large amount of (3Z)-nonenal, putative (2Z)-nonenal, and $(2 E)$-nonenal was detected in this reaction (Figure 5A and $5 \mathrm{~B}$ ). Reaction mixtures containing only LOX or HPL enzymes were devoid of $\mathrm{C}_{6^{-}}$and $\mathrm{C}_{9}$-aldehydes (Figure $5 \mathrm{~A}$ and $5 \mathrm{~B}$ ). One milligram of crude Cm-9/13-HPL preparation could produce $3317 \pm 528 \mathrm{nmol}$ total $\mathrm{C}_{9}$-aldehydes in a reaction mixture containing yeast crude extract expressing Nb-9-LOX and linoleic acid after $30 \mathrm{~min}$ (Table 2). The yield of $\mathrm{C}_{9}$-aldehydes from linoleic acid was $64 \%$.

The second cleavage product 9-oxo-nonanoic acid formed by 9 -HPL activity was analyzed by LC-MS. A large peak in the ion trace $m / z 171$ with a retention time of $19.0 \mathrm{~min}$ was detected in the reaction mixtures with linoleic acid and Nb-9-LOX in combination with Cm-9/13-HPL (Figure 5C). The MS/MS spectrum of the pseudomolecular ion $[\mathrm{M}-\mathrm{H}]^{-}$ion $(\mathrm{m} / z$ 171) showed characteristic ions $m / z 155$ [M-H-O] $^{-}, \mathrm{m} / \mathrm{z} 153$ [M-H$\left.\mathrm{H}_{2} \mathrm{O}\right]^{-}$, and $m / z 127$ [M-H-CO $]^{-}$(Figure 5D), and was putatively identified as 9-oxo-nonanoic acid. No major product was detected in the reactions containing $\mathrm{Nb}-9$ LOX alone or Nb-9-LOX in combination with Cl-13HPL (Figure 5C).

\section{Biocatalytic hydroxylation of linoleic acid with Nb-9-LOX and cysteine}

Fatty acids with multiple functional groups can serve as monomers for polymerization and can be employed to produce other useful compounds [35,36]. In this study, we used a convenient and effective reduction step of hydroperoxides developed by Elshof et al. [38] to prepare 9-hydroxy-10(E),12(Z)-octadecadienoic acid (9HOD). In this system, the enzymatic large-scale preparation of unsaturated fatty acid hydroperoxides is the first step in the preparation of the corresponding fatty acid hydroxides. A crude extract from yeast cells expressing $\mathrm{Nb}-9-\mathrm{LOX}$ was used as the source of lipoxygenase and cysteine as a mild reducing agent, while the primary substrate was linoleic acid (Figure 6). Products generated by incubation of linoleic acid and yeast cell extracts expressing Nb-9-LOX with cysteine were analyzed by LC-MS. We monitored $m / z 319[\mathrm{M}+\mathrm{Na}]^{+}$to detect the production of 9-HOD, whereas for detection of 9HPOD and linoleic acid $m / z 335[\mathrm{M}+\mathrm{Na}]^{+}$and $m / z 279$ [M-H] $]^{-}$was monitored, respectively. A large peak at $m / z$ 319 (9-HOD) was detected when the reaction mixture contained cysteine. Although 9-HOD and 9-HPOD showed almost identical retention times they could clearly be distinguished by their mass spectral data. In contrast, only a tiny amount of 9-HOD was detected in the reaction without cysteine (Figure 7). Moreover, no remaining linoleic acid was detectable in both reactions. 


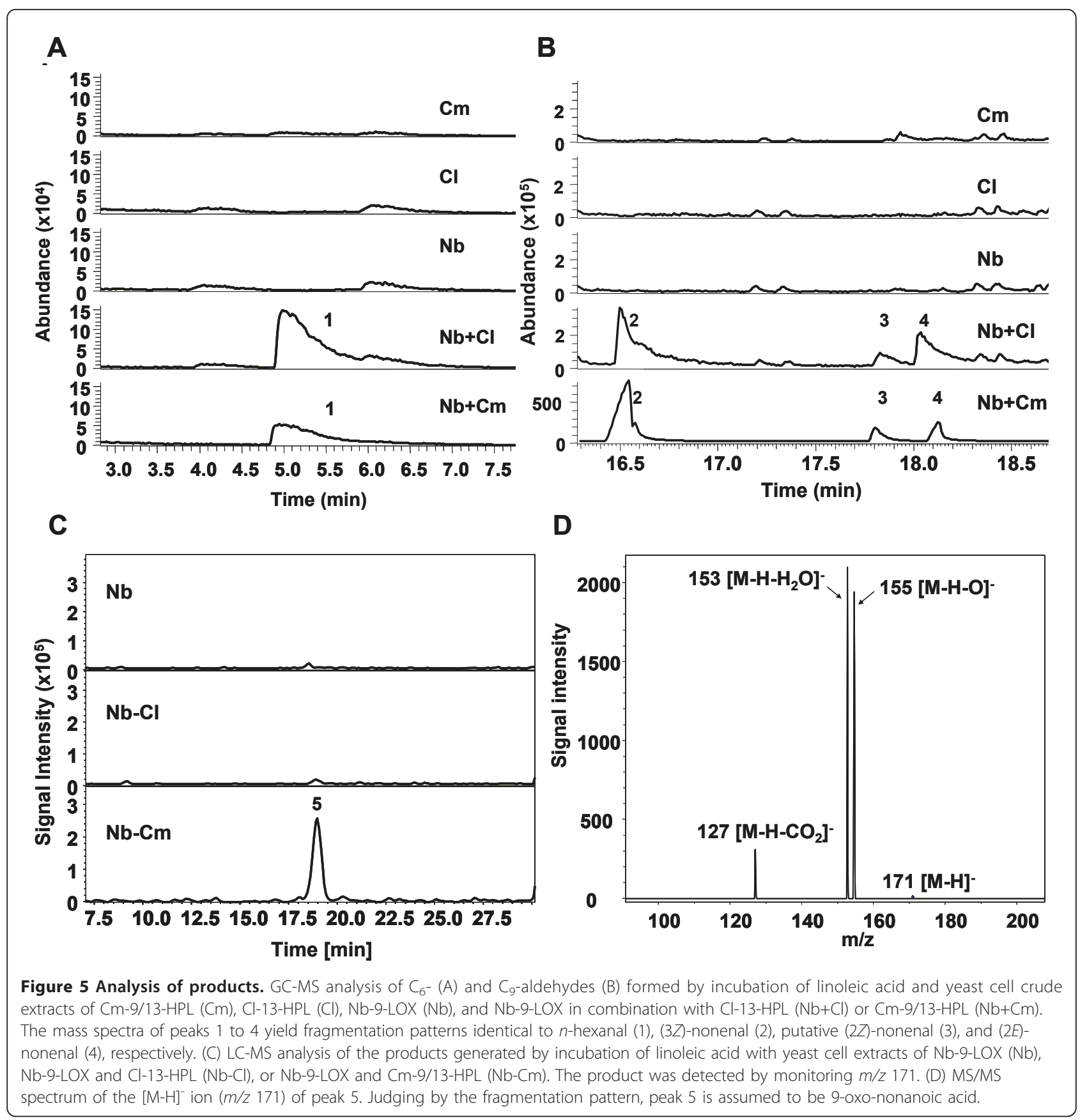

Table 2 Formation of $\mathrm{C}_{6}$ - and $\mathrm{C}_{9}$-aldehydes from linoleic acid in different combinations of LOX and HPL enzymes

\begin{tabular}{|c|c|c|c|c|}
\hline & $\begin{array}{c}n \text {-Hexanal } \\
\left(\text { nmol } \mathrm{mg}^{-1} \text { protein*) }\right.\end{array}$ & $\begin{array}{c}\text { (3Z)-Nonenal } \\
\text { (nmol mg-1 protein*) }\end{array}$ & 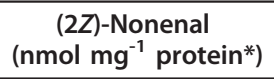 & $\begin{array}{c}\text { (2E)-Nonenal } \\
\left(\mathrm{nmol} \mathrm{mg}^{-1} \text { protein*) }\right.\end{array}$ \\
\hline$\overline{\mathrm{Nb}-\mathrm{Cl}}$ & $48 \pm 28$ & $1.9 \pm 1.6$ & $0.41 \pm 0.37$ & $0.17 \pm 0.15$ \\
\hline $\mathrm{Nb}-\mathrm{Cm}$ & $30 \pm 13$ & $2527 \pm 316$ & $360 \pm 100$ & $430 \pm 143$ \\
\hline
\end{tabular}

\footnotetext{
* Crude extracted protein.
}

$\mathrm{Nb}$, yeast expressed $\mathrm{Nb}-9-\mathrm{LOX} ; \mathrm{Cl}$, yeast expressed $\mathrm{Cl}-13-\mathrm{HPL} ; \mathrm{Cm}$, yeast expressed $\mathrm{Cm}-9 / 13-\mathrm{HPL}$. The amount of $n$-hexanal and various nonenal isomers were determined using standard curves calculated from various known concentrations of $n$-hexanal and (2E)-nonenal against the mass peak areas which were recorded by SPME-GC-MS, respectively. Each value is the average and standard error of three replicates. 


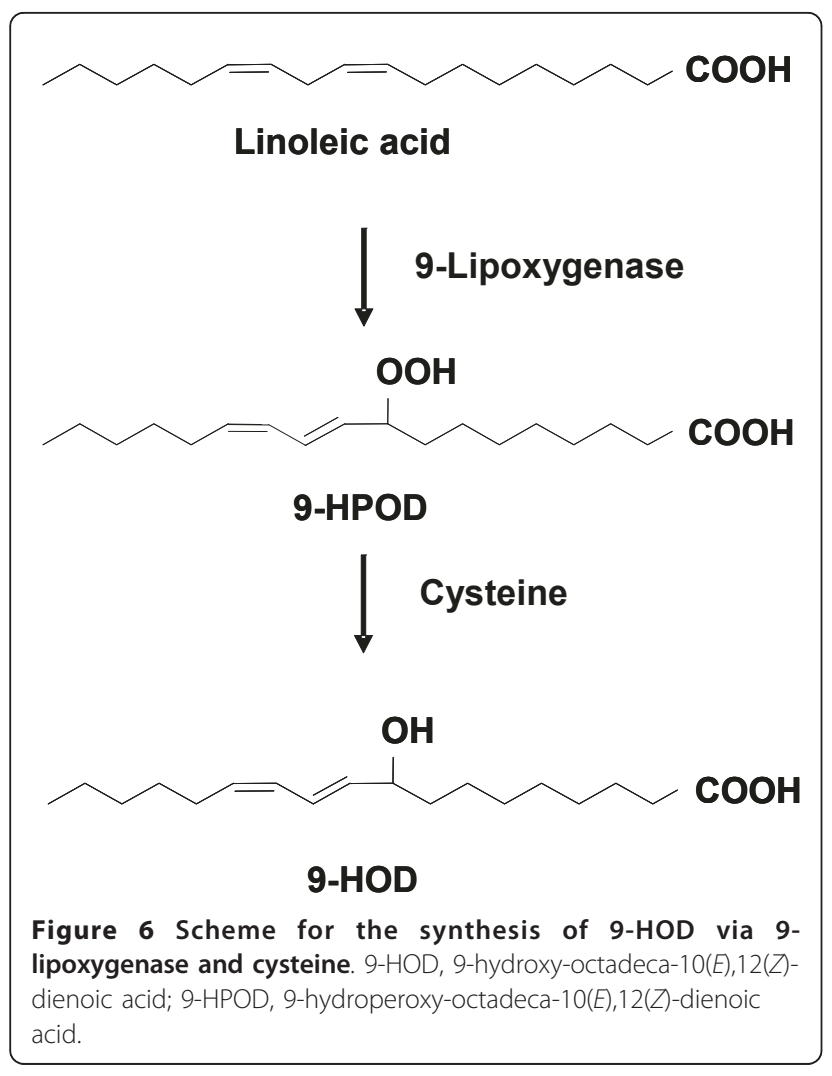

In order to develop an optimal system for production of 9-HOD in a biocatalytic process, a series of experiments was performed. At first, the ratio of substrate/ cysteine was tested. Linoleic acid $(600 \mu \mathrm{M})$ was incubated with Nb-9-LOX and different concentrations of cysteine: $300 \mu \mathrm{M}, 600 \mu \mathrm{M}, 1200 \mu \mathrm{M}, 2400 \mu \mathrm{M}$, and $4800 \mu \mathrm{M}$. Figure $8 \mathrm{~A}$ shows that the amount of 9-HOD (peak 2) increased with rising levels of cysteine. The best ratio of substrate/cysteine was $1 / 4$ (Figure $8 \mathrm{~B}$ ). A cysteine concentration of more than 4 times that of linoleic acid did not increase the production of 9-HOD. The reaction time was also tested. When the ratio of substrate:cysteine was 1:4, most 9-HPOD was reduced to 9-HOD after two hours (Figure $8 \mathrm{C}$ ).

For biocatalytic production of 9-HOD, we synchronously added enzyme (Nb-9-LOX-yeast extracts, 0.075 $\left.\mathrm{U} \mathrm{ml}^{-1}\right)$, linoleic acid $(1.5 \mathrm{mM})$, and cysteine $(6 \mathrm{mM})$ into the bioreactor containing $50 \mathrm{mM}$ citrate buffer, $\mathrm{pH}$ 6.0 , at $35^{\circ} \mathrm{C}$ for $2 \mathrm{hrs}$ with gentle shaking at $150 \mathrm{rpm}$. The products were then extracted with diethylether and analyzed by LC-MS. The result showed that linoleic acid was completely consumed and most 9-HPOD was reduced to 9-HOD (Figure 7). Under this condition, the yield of 9-HOD from linoleic acid was $72 \%$ (Table 3). The total amounts of starting material for the production of $1 \mathrm{~g}$ of 9-HOD are shown in Table 3. Our system is a very simple batch process, no extensive mixing is required, and no foaming occurs.

\section{Discussion}

Enhancement of LOX expression in response to fungal, bacterial, and viral pathogen ingress appears to be a general feature occurring both in monocots and dicots. Fournier et al. [46] showed that LOX gene expression and activity were induced after root inoculation with zoospores of Phytophthora parasitica var. Nicotinanae $(P p n)$. The purified LOX from elicited tobacco cells and infected tobacco plants yielded a single band in SDS/ PAGE, suggesting that only one LOX isoform might be induced by the pathogen and its elicitors. In vitro enzyme assay showed this LOX displayed predominance for the 9-LOX function [46]. Furthermore, a previous study for LOX gene expression in tobacco cell-suspension cultures and intact plants in response to infection with Ppn showed that the LOX gene was not constitutively expressed to a detectable level in control cells and healthy plants. In contrast, a rapid and transient accumulation of transcripts occurred in cells and plants after treatment with elicitor and inoculation with zoospores of Ppn, respectively [43]. In this work, we also demonstrated that both gene expression and enzyme activity of 9-LOX were induced in $N$. benthamiana leaves treated with agrobacterium suspensions which carried TMVbased vectors. 9-LOX activity was not induced in the leaves after wounding. However, it was induced in all leaves treated with agrobacterium suspension (Figure 1B). LOX gene expression and enzyme activity were even more strongly induced when leaves were treated with agrobacterium suspension carrying 3'-provector, 5'provector and integrase provector which are assembled in the plant cell to form a fully functional infective RNA replicon. The fully functional RNA replicon is able to replicate autonomously within each infected cell [41,42]. Our data indicate that $\mathrm{Nb}-9-\mathrm{LOX}$ expression is induced by agrobacterium attack and also by TMV infection. The stimulation of LOX activity has also been reported in tobacco after infection with TMV [47]. Infection with TMV has been suggested to result in localized necrotic lesions in hypersensitively reacting tobacco plants [47]. Besides, lipid peroxidation analyses in relation with the hypersensitive reaction in cryptogein-elicited tobacco leaves suggested that 9-fatty acid hydroperoxides are responsible for tissue necrosis [5,7].

Three LOX genes have been isolated from tobacco Nicotiana attenuata, namely NaLOX1, NaLOX2, and NaLOX3 [48]. Nb-9-LOX showed 82, 40, and $42 \%$ amino acid identity with NaLOX1, NaLOX2, and NaLOX3, respectively. We suggest that Nb-9-LOX has the same function as NaLOX1 because Nb-9-LOX shows a high amino acid identity with NaLOX1, the 


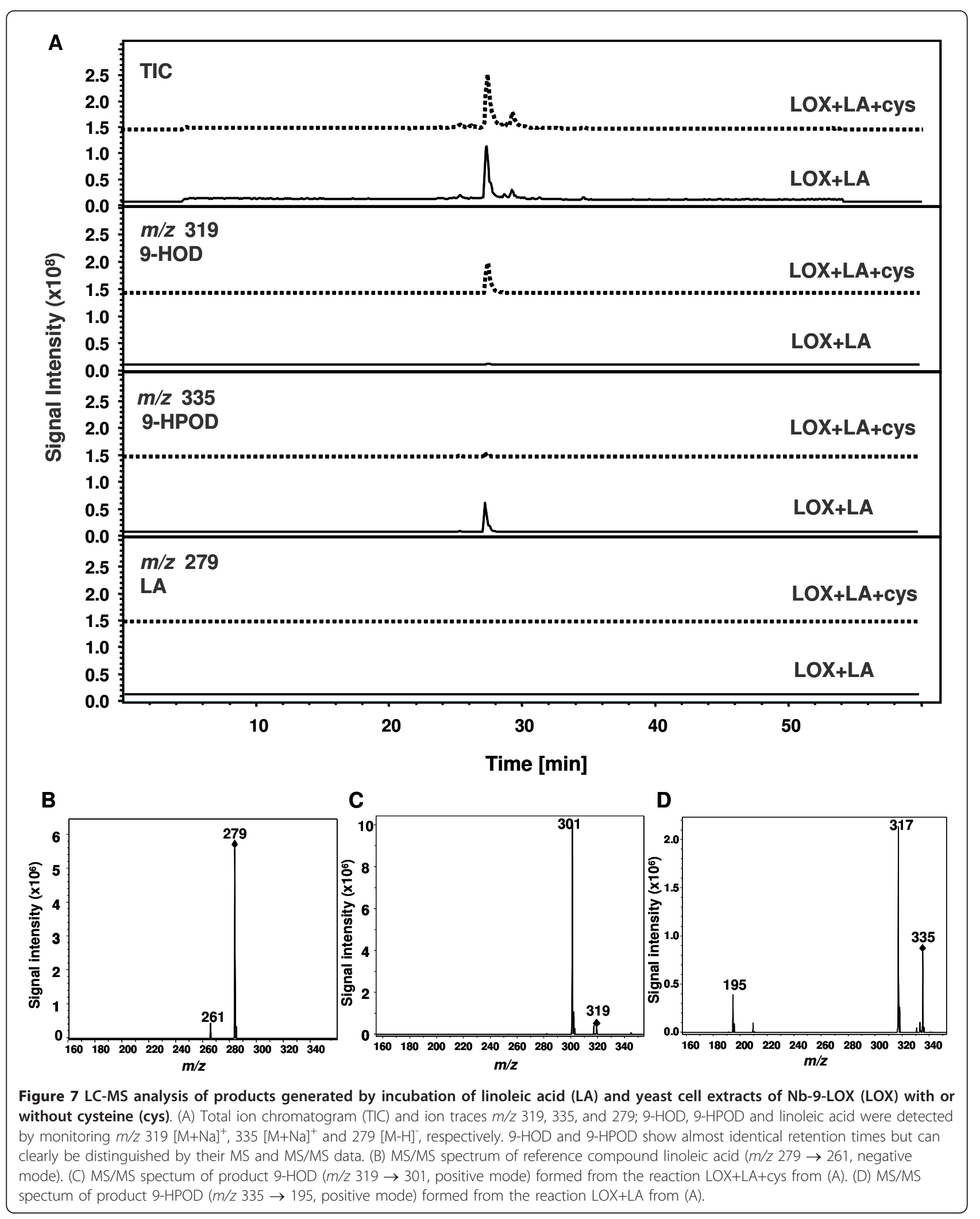



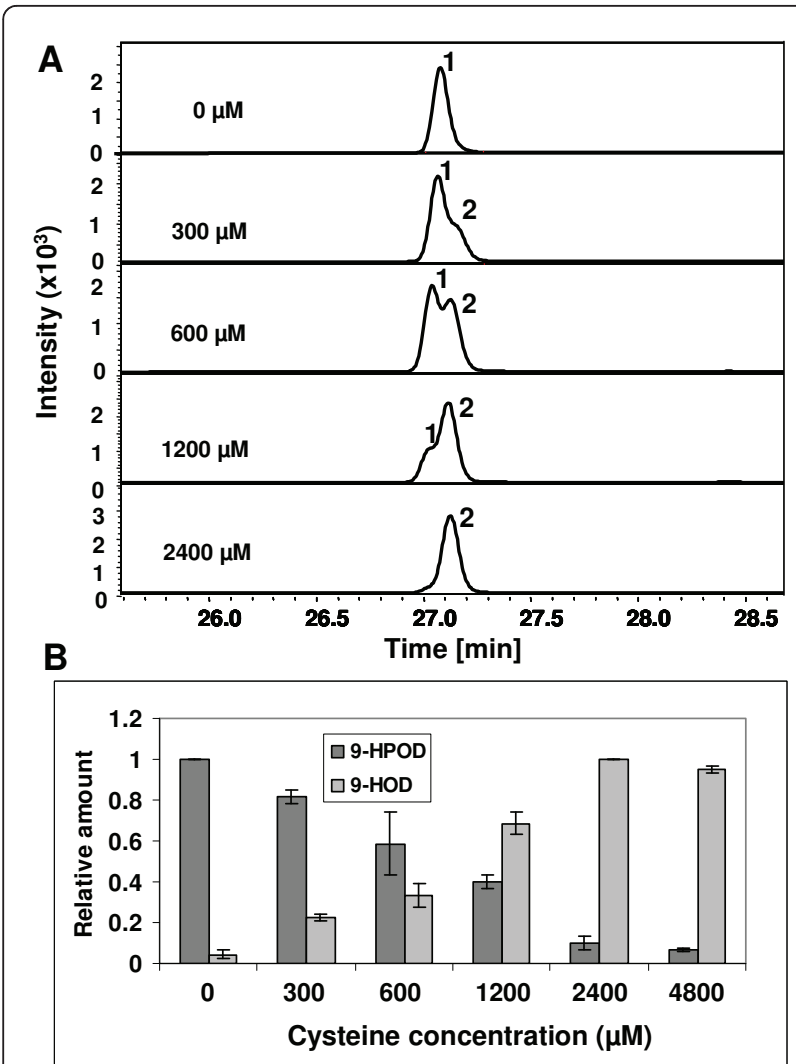

C

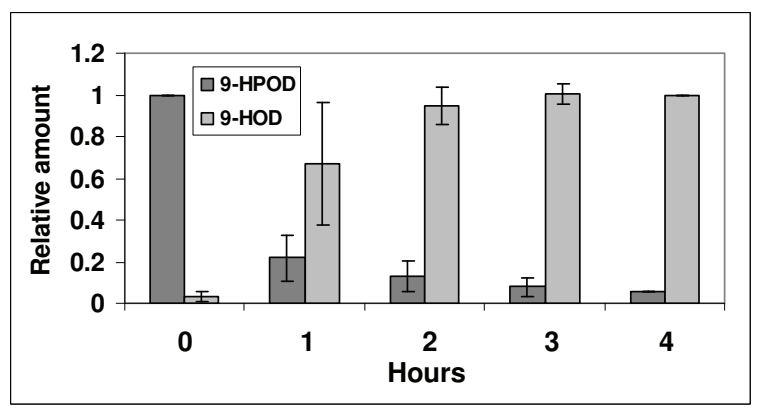

Figure 8 The effects of cysteine levels and reaction periods on the product profile. Linoleic acid $(600 \mu \mathrm{M})$ was incubated with yeast extract expressing $\mathrm{Nb}-9-\mathrm{LOX}$ and different concentrations of cysteine at $35^{\circ} \mathrm{C}$ for 1 hour. The product was detected by LC-MS. (A) Ultraviolet detection at $234 \mathrm{~nm}$. Peak 1, 9-HPOD; peak 2, 9-HOD. The concentrations of cysteine are given. (B) Relative amounts of 9HPOD and 9-HOD calculated from LC-MS analysis of peak 1 (9HPOD) and peak 2 (9-HOD) from (A). (C) Relative amounts of 9HPOD and 9-HOD calculated from LC-MS analysis of products formed from the reaction containing $600 \mu \mathrm{M}$ of linoleic acid, yeast extract expressing Nb-9-LOX, and $2.4 \mathrm{mM}$ of cysteine at $35^{\circ} \mathrm{C}$ after different reaction periods. The production of $9-\mathrm{HPOD}$ was monitored at $\mathrm{m} / \mathrm{z} 335[\mathrm{M}+\mathrm{Na}]^{+}$, and of 9-HOD at $\mathrm{m} / \mathrm{z} 319[\mathrm{M}+\mathrm{Na}]^{+}$ The highest amount was defined as 1 . Each bar represents the mean and standard error of three replicates.
Table 3 Starting material needed for production of $1 \mathrm{~g}$ of 9-HOD

\begin{tabular}{ll}
\hline Material & Amount \\
\hline Linoleic acid & $1.3 \mathrm{~g} \mathrm{(1.5} \mathrm{mM)}$ \\
Yeast culture for extraction of Nb-9-LOX & $260 \mathrm{ml}^{*}(234 \mathrm{units})$ \\
Citric acid & $33 \mathrm{~g} \mathrm{(50} \mathrm{mM,} \mathrm{pH} \mathrm{6.0)}$ \\
Cysteine & $3.3 \mathrm{~g} \mathrm{(6} \mathrm{mM)}$ \\
\hline Yield & $72 \%$ \\
\hline
\end{tabular}

* The number was calculated from the data shown in Table 1.

transcripts of both genes were not detectable in untreated leaf and their transcripts were not induced by wounding. Furthermore, NaLOX1 expression is also strongly induced by pathogen infection, and is unlikely to be involved in wounding-induced production of jasmonate [48].

The product specificity of $\mathrm{Nb}-9$-LOX was examined by incubation of linoleic acid and Nb-9-LOX in combination with Cl-13-HPL or Cm-9/13-HPL. The reaction products were analyzed by UV-spectrophotometry, LCMS and SPME-GC-MS. Figure 4D shows that the absorbance did not decrease when Cl-13-HPL was added to the reaction containing $\mathrm{Nb}-9-\mathrm{LOX}$ and linoleic acid, indicating that the hydroperoxide produced by $\mathrm{Nb}-9$ LOX from linoleic acid was not cleaved by Cl-13-HPL. In contrast, the addition of Cm-9/13-HPL caused a decrease of absorbance. The reaction product formed by incubation of linoleic acid with $\mathrm{Nb}-9$-LOX was analyzed by LC-MS. 9-HPOD was the main hydroperoxide product, while 13-HPOD was not detectable (Figure 2S). The result from SPME-GC-MC showed that low levels of $\mathrm{C}_{6}$-aldehyde and $\mathrm{C}_{9}$-aldehyde were produced during the reaction of linoleic acid with recombinant $\mathrm{Nb}$-9LOX in combination with recombinant Cl-13-HPL (Figure 5). This result suggested that Nb-9-LOX functions like 13-LOX to some small extent. The low level of 13HPOD was further metabolized into hexanal by Cl-13HPL. As a large amount of 9-hydroperoxide substrates is formed in the reaction, a detectable level of $\mathrm{C}_{9}$-aldehydes can be produced in spite of low activity of Cl-13HPL toward 9-hydroperoxides [12,44]. Likewise, the low level of 13-HPOD was further metabolized into a small amount of hexanal by Cm-9/13-HPL. However, the high level of 9-hydroperoxide was converted into a large amount of $\mathrm{C}_{9}$-aldehydes by Cm-9/13-HPL which displayed high 9-HPL activity (Figure 5). The results of SPME-GC-MS revealed that Nb-9-LOX possesses high 9-LOX specificity with a tiny share of 13-LOX activity, although 13-product was not detected by LC-MS. This result could also explain why a low level of $\mathrm{C}_{6}$-aldehydes 
and $\mathrm{C}_{9}$-aldehydes were detected when fatty acids were incubated with $\mathrm{Cl}-\mathrm{HPL}$ treated leaf extracts (displayed high activity of both 9-LOX and 13-HPL) as described previously [12].

Chemical synthesis is the easiest way to produce large amounts of $\mathrm{C}_{6}$ - or $\mathrm{C}_{9}$ - aldehydes and alcohols. However, for food application, consumers have a strong preference for naturally synthesized additives and aromas. Due to the high demand for such natural flavours, many groups have attempted to develop a biocatalytic process to produce these compounds on a large scale. During the past years, enzymatic syntheses using LOX and HPL as biocatalysts have become popular for large scale production of $\mathrm{C}_{6}$-aldehydes [28]. For this purpose, production of stable LOX and HPL with high enzymatic activity is the first step. Heterologous gene expression in plants, yeast cells, or bacteria would be an excellent method to increase the availability of LOX and HPL for that purpose. Different sources of HPLs have been explored for industrial production of $\mathrm{C}_{6}$-aldehydes using soybean flour as a source of stable LOX. For example, a recombinant alfalfa 13-HPL expressed in $E$. coli in combination with soybean LOX resulted in yields of $50 \%$ for hexanal and $26 \%$ for hexenal from vegetable oils [49]. A combination of watermelon 13-HPL-overexpressing tobacco leaf tissue and soybean LOX2 yielded $50 \%$ of hexenals from linolenic acid [50]. A combination of HPL isolated from green bell pepper and soybean LOX1 isolated from defatted soybean meal resulted in 37\% yield for the hexenal isomers from linseed oil [51]. In addition, a yield of $60 \%$ for (3Z)-hexenal from linolenic acid was obtained via the combination of a $13-\mathrm{HPL}$ isolated from sugar beet leaves and soybean LOX1 [52]. Besides, a combination of watermelon 13-HPL-overexpression tobacco leaf tissues and soybean VLXC expressed in yeast yielded 93\% hexanal from linoleic acid [12]. However, up to now no study has described the production of $\mathrm{C}_{9}$-aldehydes on a large scale. In this study, we isolated a 9-LOX gene responding to pathogen attack from $N$. benthamiana leaves. We have successfully expressed this LOX gene (Nb-9-LOX) together with a 9-HPL $(C m-9 / 13-H P L)$ in yeast cells. The yeast cells expressed $0.9 \mathrm{U} \mathrm{ml}^{-1}$ and $0.1 \mathrm{U} \mathrm{ml}^{-1}$ cell cultures of stable 9-LOX and 9-HPL, respectively. Our results showed that the combination of recombinant $\mathrm{Nb}-9$-LOX and recombinant $\mathrm{Cm}-9 / 13-\mathrm{HPL}$ could produce large amounts of $\mathrm{C}_{9}$-aldehydes. The yield was $64 \%$ for nonenal isomers together from linoleic acid (Table 2). Only a very low level of $\mathrm{C}_{6}$-aldehyde was formed (about 1/100 of that of $\mathrm{C}_{9}$-aldehydes, Table 2). Therefore, this system has potential for producing $\mathrm{C}_{9}$ compounds on a large scale.

A number of reagents have been used to reduce hydroperoxides into the corresponding hydroxides
[37-39]. However, not all of them are suitable and economically attractive for a biocatalytic process. Cysteine is a mild reducing agent which has been used to effectively reduce hydroperoxides into the corresponding hydroxides in a bioprocess [38]. Based on this, we tried to produce 9-HOD using yeast expressed $\mathrm{Nb}$-9-LOX and cysteine. Cell lysates containing 9-LOX activity can be easily and rapidly prepared from yeast cells using glass beads. In this system, the enzymatic large-scale preparation of unsaturated fatty acid hydroperoxides is the first step in the preparation of the corresponding fatty acid hydroxides. Large-scale conversion of fatty acids into hydroperoxides by soybean LOX has been successfully accomplished [53-55]. In order to obtain high yields of hydroperoxides, some points have to be taken into account: the optimal enzyme/substrate ratio, the substrate concentration, and adequate oxygen supply. At high substrate concentration, fatty acids form aggregates which are not easily dispersible in buffer [53]. A low oxygen concentration may eventually lead to an anaerobic reaction resulting in unwanted side-products [54]. Besides, Elshof et al. [38] pointed out that higher conversion yields could be obtained with gradual additions of substrate and enzyme. For obtaining high yields of hydroxides, also the optimal substrate/cysteine ratio and time point of adding of cysteine to the incubation mixture have to be considered [38]. In our system, we synchronously added enzyme (Nb-9-LOX-yeast crude extracts), linoleic acid, and cysteine into the bioreactor. The dioxygenation of linoleic acids by yeast expressed Nb-9-LOX resulted in high yields of hydroperoxy fatty acids. The use of the mild reducing agent cysteine makes it simple and efficient to produce 9-HOD. The biocatalytic process described here allows rapid and cost-efficient generation of HFAs in one experimental step. The procedure is simple because it requires no solvent or surfactant, and is conducted at atmospheric pressure.

\section{Conclusions}

We have isolated a 9-LOX gene from $N$. benthamiana, which is induced by pathogen attack. This LOX gene could be expressed in yeast cells in stable and large amounts. It efficiently transforms linoleic acid to 9HPOD. This LOX gene can be used to produce $\mathrm{C}_{9}$-aldehydes in combination with a HPL gene with 9-HPL function, or to produce 9-HOD in a biocatalytic process in combination with cysteine as a mild reducing agent.

\section{Methods \\ Chemicals}

Chemicals used were standard commercial products of analytical grade from the following companies: linoleic acid (Roth, Karlsruhe, Germany); 9(S)-HPOD and 13(S)- 
HPOD (Biozol Diagnostica, Eching, Germany); cysteine (Sigma, Steinheim, Germany); citric acid monohydrate (Merck, Darmstadt, Germany).

\section{Wounding treatment of leaves}

For investigation of effect of wounding on $\mathrm{Nb}-9-\mathrm{LOX}$ gene expression, leaves of $N$. benthamiana were infiltrated with buffer (10 mM 2- $\mathrm{N}$-morpholino-ethanesulfonic acid (MES) $\mathrm{pH} 5.5,10 \mathrm{mM} \mathrm{MgSO}_{4}$ ) and were harvested at $30 \mathrm{~min}, 1 \mathrm{~h}, 2 \mathrm{~h}, 6 \mathrm{~h}, 24 \mathrm{~h}$, and $48 \mathrm{~h}$ after wounding.

\section{Viral vectors and agroinfiltration}

The viral vector system based on cr-TMV (cruciferinfecting tobacco mosaic virus) is an expression system that relies on in planta assembly of functional viral vectors from separated pro-vector modules $[41,42]$. The 5' module (pICH17388) contains the 5' part of the viral vector including the RNA-dependent RNA polymerase, movement protein genes, the coat protein subgenomic promoter, and a loxP site. The 3' module (pICH11599) contains a loxP site, cloning sites for cloning of the gene of interest (unused in the present study), and the 3' end of the viral vector. Both modules are assembled inside a plant cell with the help of a site-specific recombinase (pICH14011) to form a fully functional RNA replicon.

Agrobacterium was used to deliver various modules into plant cells. pICH17388, pICH14011, and pICH11599 were separately transformed into the Agrobacterium tumefaciens strain AGL0 using the freezethaw technique as described by Höfgen and Willmitzer [56], and integrity was confirmed by PCR. Agrobacterium strains carrying each pro-vector module were mixed and infiltrated into $N$. benthamiana using a syringe without a needle as described [12].

\section{Real-time RT-PCR analysis}

Total RNA was extracted from leaves of transfected $N$. benthamiana and untreated control plants using the CTAB extraction procedure [57]. RNA samples were treated with RNase free DNase I (Fermentas, St. LeonRot, Germany) for $1 \mathrm{~h}$ at $37^{\circ} \mathrm{C}$. First strand cDNA synthesis was performed in duplicate in a $20 \mu \mathrm{l}$ reaction volume, with $1 \mu \mathrm{g}$ of total RNA as the template, random primer (random hexamer, $100 \mathrm{pmol}$ ), and M-MLV reverse transcriptase (200 U, Invitrogen, Karlsruhe, Germany) according to the manufacturer's instructions. Real-time PCR was performed as described by Huang et al.[12]. A relative quantification of gene expression was performed using an $18 \mathrm{~S}-26 \mathrm{~S}$ interspacer gene as a reference [58]. Primers for the amplification of $18 \mathrm{~S}-26 \mathrm{~S}$ interspacer gene were 5'-ACC GTT GAT TCG CAC AAT TGG TCA TCG-3' (forward) and 5'-TAC TGC GGG TCG GCA ATC GGA CG-3' (reverse). The primers used for the target gene $\mathrm{Nb}$-9-LOX were $5^{\prime}$ ATA TGT GCC AAG GGA CGA-3' (forward) and 5'AAT AGG CCT TCG CCA TCA-3' (reverse). Relative expression ratio was calculated and normalized using an 18S-26S interspacer gene [58].

\section{Cloning of full length CDNAs of Nb-9-LOX, Cl-13-HPL and Cm-9/13-HPL}

Total RNA was isolated from leaves of $N$. benthamiana treated with viral vectors, leaves of watermelon (Citrullus lanatus), and fruit of melon (Cucumis melo) by CTAB extraction [57]. The first-strand cDNAs were synthesized from $10 \mu \mathrm{g}$ of total RNA using Superscript III RTase (Invitrogen, Karlsruhe, Germany) and a GeneRacer oligo-dT primer (5'-GCT GTC AAC GAT ACG CTA CGT AAC GGC ATG ACA GTG T $(18)^{-3}$ ').

The coding regions of $\mathrm{Nb}-9-\mathrm{LOX}, \mathrm{Cl}-13-\mathrm{HPL}$, and Cm-9/13-HPL were amplified by RT-PCR with the corresponding cDNA template prepared as described above. The primers were Nb-9-LOX-S and Nb-9-LOXAS (Table 4, design based on a tobacco 9-LOX gene, accession number X84040) for $N b-9-L O X, C l H P L-S$ and ClHPL-AS (Table 4, design based on a watermelon HPL gene, accession number AY703450) for Cl-13-HPL, and CmHPL-S and CmHPL-AS (Table 4, design based on a melon HPL gene, accession number AF081955) for $\mathrm{Cm}$ 9/13-HPL. The temperature program used was $5 \mathrm{~min}$ at $95^{\circ} \mathrm{C}, 1$ cycle; $45 \mathrm{sec}$ at $95^{\circ} \mathrm{C}, 45 \mathrm{sec}$ at $55^{\circ} \mathrm{C}, 2 \mathrm{~min}$ at $72^{\circ} \mathrm{C}, 35$ cycles; final extension at $72^{\circ} \mathrm{C}$ for $10 \mathrm{~min}$. The PCR products amplified with Phusion enzyme polymerase (New England Biolabs, Frankfurt, Germany) were Atailed with Taq-DNA polymerase and ligated into the pGEM-T vector (Promega, Mannheim, Germany). The recombinant genes were subjected to sequencing to confirm the sequence of the inserts.

\section{Expression of $\mathrm{Nb}-9-\mathrm{LOX}, \mathrm{Cl}-13-\mathrm{HPL}$, and $\mathrm{Cm}-9 / 13 \mathrm{HPL}$ in yeast}

The full-length open reading frames of $\mathrm{Nb}-9-\mathrm{LOX}, \mathrm{Cl}$ 13-HPL, and Cm-9/13-HPL were excised from pGEM-T vectors (constructed as described above), and cloned into pYES2 vectors (Invitrogen, Karlsruhe, Germany) to generate pYES2-Nb-9-LOX, pYES2-Cl-13-HPL, and pYES2-Cm-9/13-HPL. Furthermore, these three constructs were transformed into the $S$. cerevisiae INVSc1 strain for expression of recombinant protein as described [12]. Time-course studies of $\mathrm{Nb}-9-\mathrm{LOX}, \mathrm{Cl}$ 13-HPL, and Cm-9/13-HPL gene expression in yeast were performed by harvesting an aliquot of cells at 0,4 , 8 , and 24 hours after galactose induction.

\section{SDS/PAGE and western blot analysis}

Western blot analysis was performed to detect the recombinant Nb-9-LOX in yeast. Total proteins $(20 \mu \mathrm{g})$ 


\begin{tabular}{|c|c|c|}
\hline Genes & Sequences & Cloning sites \\
\hline \multirow[t]{2}{*}{ Nb-9-LOX } & Forward: 5'-CGGGGTACCAACACAATGTCTCTGGAGAAGATT-3' & $\mathrm{Kpnl} / \mathrm{Notl}$ \\
\hline & Reverse: 5'- ATTGCGGCCGCCTATATTGACACACTGTT-3' & \\
\hline \multirow[t]{2}{*}{ Cm-9/13-HPL } & Forward: 5'- CGCGGATCCTACACAATGTCTACTCCTTCTTCC-3' & BamHI/Xhol \\
\hline & Reverse: 5'- CCGCTCGAGTTAAACCATATCGGTTGC-3' & \\
\hline \multirow[t]{2}{*}{$\mathrm{Cl}-13-\mathrm{HPL}$} & Forward: 5'- CGGGGTACCAACACAATGAAGGTCACCATGACC-3' & $\mathrm{Kpnl} / \mathrm{Notl}$ \\
\hline & Reverse: 5'- ATTGCGGCCGCTCAGTTGGTCCTTTGAAA-3' & \\
\hline
\end{tabular}

The underlined nucleotide sequences indicate the sites of the restriction enzymes for insertion into multiple cloning sites of a plasmid.

were separated on a $12 \%$ Tris-glycine SDS/PAGE gel (Anamed, Groß-Bieberau, Germany), and then electrophoretically transferred onto a PVDF membrane (Roth, Karlsruhe, Germany). The Nb-9-LOX protein was detected with a polyclonal rabbit anti-LOX antibody (product number: AS06 128, Agrisera, Vännäs, Sweden) as described by Huang et al. [12].

\section{Enzyme extraction and assay}

For analysis of the LOX activity in tobacco leaves, one hundred milligram (fresh weight) samples of $N$. benthamiana leaves infiltrated with Agrobacterium were ground into a fine powder in liquid nitrogen with a mortar and a pestle, followed by being resuspended in $300 \mu \mathrm{l}$ of protein extraction buffer $(50 \mathrm{mM}$ sodium phosphate buffer, $\mathrm{pH} 7.5,10 \mathrm{mM}$ EDTA, $0.1 \%$ Triton $\mathrm{X}$-100, $5 \mathrm{mM} \beta$-mercaptoethanol). The homogenate was centrifuged at $4^{\circ} \mathrm{C}, 16,000 \times \mathrm{g}$ for $10 \mathrm{~min}$ to remove the cell debris. Total protein content was determined by Bradford assay. LOX activity was determined in $500 \mu \mathrm{l}$ of $50 \mathrm{mM}$ sodium phosphate buffer ( $\mathrm{pH}$ 7.0) containing $3 \mu \mathrm{l}$ of $N$. benthamiana leaf extracts and $600 \mu \mathrm{M}$ of linoleic acid at $25^{\circ} \mathrm{C}$ with constant shaking for $30 \mathrm{~min}$. The reaction products were extracted with chloroform/ methanol $(2: 1, \mathrm{v} / \mathrm{v})$, evaporated to dryness, resuspended in 30\% methanol, and analyzed by LC-MS as described by Huang et al. [12].

For analysis of LOX and HPL activities in yeast extracts, yeast cells were harvested by centrifugation and resuspended in a volume of breaking buffer $(50 \mathrm{mM}$ sodium phosphate buffer, pH 7.5, 1 mM EDTA, 5\% glycerol, $1 \mathrm{mM}$ PMSF) to obtain an $\mathrm{OD}_{600}$ of 50 . Cell lysates were prepared using glass beads by vortexing mixture for $30 \mathrm{sec}-$ onds, followed by 30 seconds on ice. The procedure was repeated ten times for a total of ten minutes. Cell debris was removed by centrifugation $\left(5000 \mathrm{~g}, 5 \mathrm{~min}, 4^{\circ} \mathrm{C}\right.$ ). Total protein content was determined by Bradford assay. LOX activity was measured at room temperature by the formation of the conjugated diene at $234 \mathrm{~nm}$. Yeast cell extracts $(1 \mu \mathrm{l})$ were added to $120 \mu \mathrm{l}$ of $50 \mathrm{mM}$ sodium phosphate buffer containing $625 \mu \mathrm{M}$ of linoleic acid and measured spectrophotometrically at $234 \mathrm{~nm}$ applying an extinction coefficient of $23000 \mathrm{M}^{-1} \mathrm{~cm}^{-1}$. Initially, LOX activity was measured at $\mathrm{pH} 7.0$, after determination of the $\mathrm{pH}$ optimum $\mathrm{pH} 6.0$ was used. HPL activity was determined in $120 \mu \mathrm{l}$ of $50 \mathrm{mM}$ sodium phosphate buffer (pH 6.0 for Cl13-HPL, and $\mathrm{pH} 7.0$ for Cm-9/13-HPL) containing $2.5 \mu \mathrm{l}$ of yeast cell extracts and $50 \mu \mathrm{M}$ of substrate $(9(S)$-HPOD or 13(S)-HPOD) at room temperature. The decrease of fatty acid hydroperoxide was measured spectrophotometrically by following the decrease of $A_{234}$ due to cleavage of the substrate by hydroperoxide lyase. The concentration of remaining substrate was calculated using an extinction coefficient of $23000 \mathrm{M}^{-1} \mathrm{~cm}^{-1}$. One unit of activity (U) corresponds to the amount of enzyme that converts $1 \mu \mathrm{mol}$ of substrate per minute.

For $\mathrm{pH}$ optimum determination, $50 \mathrm{mM}$ citric acid was used for $\mathrm{pH}$ range of 4-6, $50 \mathrm{mM}$ phosphate buffer for $\mathrm{pH}$ range of 6-8 and $50 \mathrm{mM}$ Tris buffer for $\mathrm{pH}$ range of 8-9.

\section{Product identification}

For analysis of aldehyde formation in a one-pot LOXHPL process, $10 \mu \mathrm{l}$ of yeast extract of Nb-9-LOX in combination with $50 \mu \mathrm{l}$ of yeast extract of $\mathrm{Cl}-13-\mathrm{HPL}$ or Cm-9/13-HPL were diluted to $2 \mathrm{ml}$ with $50 \mathrm{mM}$ sodium phosphate buffer ( $\mathrm{pH} 7.0$ ) containing $0.15 \mathrm{mM}$ linoleic acid. The mixture was incubated for $30 \mathrm{~min}$ at $25^{\circ} \mathrm{C}$ with constant shaking in a $20 \mathrm{ml}$ reaction vial closed with a septum. Headspace compounds were trapped by SPME $(65 \mu \mathrm{m}$ polydimethylsiloxane-divinylbenzene coated fibre, Supelco, Steinheim, Germany) at $45^{\circ} \mathrm{C}$ for $30 \mathrm{~min}$. Subsequently, the SPME fibre was introduced into the GC injector and thermally desorbed volatiles analyzed by MS [12]. Diagnostic ions for hexanal were $m / z 72$ and 82 , whereas $m / z 69$ and 83 were used for nonenal. The amount of $n$-hexanal and various nonenal isomers were determined using standard curves calculated from various known concentrations of $n$-hexanal and $(2 E)$-nonenal against the mass peak areas which were recorded by SPME-GC-MS, respectively.

For analysis of non-volatile reaction products formed in a one-pot LOX-HPL process, $10 \mu$ l yeast extract of $\mathrm{Nb}-9-\mathrm{LOX}$ and $40 \mu \mathrm{l}$ yeast extract of Cm-9/13-HPL or 
of Cl-13-HPL were added to $500 \mu \mathrm{l}$ of $50 \mathrm{mM}$ sodium phosphate buffer (pH 7.0) containing $600 \mu \mathrm{M}$ linoleic acid at $25^{\circ} \mathrm{C}$ with constant shaking for 1 hour. The reaction products were extracted with chloroform/methanol $(2: 1, \mathrm{v} / \mathrm{v})$, evaporated to dryness, resuspended in $30 \%$ methanol, and analyzed by LC-MS. The HPLC system consisted of a quaternary pump and a variable wavelength detector, all from Agilent 1100 (Bruker Daltonics, Bremen, Germany). The column was a LUNA C18 100A $150 \times 2 \mathrm{~mm}$ (Phenomenex, Aschaffenburg, Germany). HPLC was performed with the following binary gradient system: solvent $\mathrm{A}$, water with $0.1 \%$ formic acid and solvent $\mathrm{B}, 100 \%$ methanol with $0.1 \%$ formic acid. The gradient program was as follows: $0-10 \mathrm{~min}, 70 \% \mathrm{~A} /$ $30 \% \mathrm{~B}$ to $50 \% \mathrm{~A} / 50 \% \mathrm{~B} ; 10-40 \mathrm{~min}, 50 \% \mathrm{~A} / 50 \% \mathrm{~B}$ to $100 \% \mathrm{~B}$, hold for $7 \mathrm{~min} ; 100 \% \mathrm{~B}$ to $70 \% \mathrm{~A} / 30 \% \mathrm{~B}$, in 3 $\mathrm{min}$, then hold for $10 \mathrm{~min}$. The flow rate was $0.2 \mathrm{ml} /$ min. Absorbances were recorded at $234 \mathrm{~nm}$ for the detection of hydroperoxy fatty acids (9- and 13-HPOD). Amounts of 9-HPOD were determined using a standard curve calculated from various known concentrations of 9-HPOD against the UV peak areas which were recorded at $234 \mathrm{~nm}$. The production of 9 -HPOD was monitored at $m / z 195\left[\mathrm{C}_{9} \mathrm{H}_{16} \mathrm{O}_{3}+\mathrm{Na}\right]^{+}$, whereas for 13HPOD $m / z 247\left[\mathrm{C}_{13} \mathrm{H}_{20} \mathrm{O}_{3}+\mathrm{Na}\right]^{+}$was monitored in positive mode. 9-Oxo-nonanoic acid was monitored at $\mathrm{m} / \mathrm{z} 171[\mathrm{M}-\mathrm{H}]^{-}$in negative mode.

For analysis of reaction products formed by Nb-9LOX and cysteine from linoleic acid, the products were partitioned into diethylether, the solution was concentrated, dissolved in 30\% methanol and analyzed by LCMS. Absorbances were recorded at $234 \mathrm{~nm}$ for the detection of 9-HPOD and 9-HOD. The production of 9HOD was monitored at $m / z 319[\mathrm{M}+\mathrm{Na}]^{+}$, whereas for detection of 9-HPOD $m / z 335[\mathrm{M}+\mathrm{Na}]^{+}$was monitored. Linoleic acid was monitored at $m / z 279[\mathrm{M}-\mathrm{H}]^{-}$. Concentrations of 9-HOD were determined using a standard curve calculated from various known concentrations of 9-HPOD against the UV peak areas which were recorded at $234 \mathrm{~nm}$ by LC-MS.

\section{Note}

Accession numbers: tobacco 9-LOX (accession number X84040), Cl-13-HPL (accession number AY703450), and Cm-9/13-HPL (accession number AF081955).

\section{Additional material}

Additional file 1: Properties of Nb-9-LOX and LC-MS analysis of products formed by Nb-9-LOX. Temperature optimum, $\mathrm{pH}$ optimum, determination of Nb-9-LOX kinetic constants, determination of $K_{m}$ value and LC-MS analysis of hydroperoxy fatty acids (HPOD) formed from linoleic acid catalyzed by Nb-9-LOX

\section{Acknowledgements}

The authors thank Professor Hans-Ulrich Koop and Dr Yuri Gleba (Icon Genetics, Halle, Germany) for the viral expression system and $N$. benthamiana seeds. Financial supports from AIF $15088 \mathrm{~N} / 1$ and 2 as well as SynRg (BMLEV) are acknowledged.

\section{Authors' contributions}

FCH isolated the 9-LOX gene, produced and characterised the recombinant protein, performed the GPCR and LC-MS analyses, and drafted the manuscript. WS conceived the study, and participated in its design and coordination. All authors read and approved the final manuscript.

Received: 19 October 2010 Accepted: 30 March 2011

Published: 30 March 2011

\section{References}

1. Siedow JN: Plant lipoxygenases: structure and function. Annu Rev Plant Physiol Plant Mol Biol 1991, 42:145-188.

2. Blee E: Biosynthesis of phytooxylipins: the peroxygenase pathway. Fett/ Lipid 1998, 100:121-127.

3. Hamberg M: An epoxy alcohol synthase pathway in higher plants: biosynthesis of antifungal trihydroxy oxylipins in leaves of potato. Lipids 1999, 34:1131-1142.

4. Axelrod B, Cheesbrough TM, Laakso S: Lipoxygenase from soybeans.Edited by: Lowenstein JM. Academic Press, New York; 1981:71:441-451, "Methods in Enzymology".

5. Rustérucci C, Montillet J-L, Agnel J-P, Battesti C, Alonso B, Knoll A, Bessoule J-J, Etienne P, Suty L, Blein J-P, Triantaphylidès C: Involvement of lipoxygenase-depent production of fatty acid hydroperoxides in the development of the hypersensitive cell death induced by cryptogein on tobacco leaves. J Biol Chem 1999, 274:36446-36455.

6. Göbel C, Feussner I, Rosahl S: Lipid peroxidation during the hypersensitive response in potato in the absence of 9-lipoxygenases. J Biol Chem 2003, 278:52834-52840.

7. Montillet J-L, Chamnongpol S, Rustérucci C, Dat J, van de Cotte B, Agnel JP, Battesti C, Inze D, van Breusegem F, Triantaphylidès C: Fatty acid hydroperoxides and $\mathrm{H}_{2} \mathrm{O}_{2}$ in the execution of hypersensitive cell death in tobacco leaves. Plant Physiol 2005, 138:1516-1526.

8. Rancé I, Fournier J, Esquerré-Tugayé M-T: The incompatible interaction between Phytophthora parasitica var. nicotianae race 0 and tobacco is suppressed in transgenic plants expressing antisense lipoxygenase sequences. Proc Natl Acad Sci USA 1998, 95:6554-6559.

9. Göbel C, Feussner I, Hamberg M, Rosahl S: Oxylipin profiling in pathogeninfected potato leaves. Biochim Biophys Acta 2002, 1584:55-64.

10. Mita G, Fasano P, De Domenico S, Perrone G, Epifani F, lannacone R, Casey R, Santino A: 9-Lipoxygenase metabolism is involved in the almond/Aspergillus carbonarius interaction. J Exp Botany 2007, 58:1803-1811.

11. Hwang IS, Hwang BK: The pepper 9-lipoxygenase gene CaLOX1 functions in defense and cell death responses to microbial pathogens. Plant Physiol 2010, 152:948-967.

12. Huang F-C, Studart-Witkowski C, Schwab W: Overexpression of hydroperoxide lyase gene in Nicotiana benthamiana using a viral vector system. Plant Biotech J 2010, 8:1-13.

13. Kolomiets MV, Hannapel DJ, Chen H, Tymeson M, Gladon RJ: Lipoxygenase is involved in the control of potato tuber development. Plant Cell 2001, 13:613-626.

14. Vellosillo T, Martínez M, López MA, Vicente J, Cascón T, Dolan L, Hamberg M, Castresana C: Oxylipins produced by the 9-lipoxygenase pathway in Arabidopsis regulate lateral root development and defense responses through a specific signaling cascade. Plant Cell 2007, 19:831-846.

15. Gao X, Shim WB, Göbel C, Kunze S, Feussner I, Meeley R, Balint-Kurti P, Kolomiets M: Disruption of a maize 9-lipoxygenase results in increased resistance to fungal pathogens and reduced levels of contamination with the mycotoxin fumonisin. MPMI 2007, 20:922-933.

16. Gao X, Starr J, Göbel C, Engelberth J, Feussner I, Tumlinson J, Kolomiets M: Maize 9-lipoxygenase ZmLOX3 controls development, root-specific expression of defense genes, and resistance to root-knot nematodes. MPMI 2008, 21:98-109. 
17. Robinson DS, Zecai W, Domoney C, Casey R: Lipoxygenase and the quality of foods. Food Chem 1995, 54:33-43.

18. Matsui K, Fukutomi S, Wilkinson J, Hiatt B, Knauf V, Kajwara T: Effect of overexpression of fatty acid 9-hydroperoxide lyase in tomatoes (Lycopersicon esculentum Mill.). J Agric Food Chem 2001, 49:5418-5424.

19. Matsui K: Green leaf volatiles: hydroperoxide lyase pathway of oxylipin metabolism. Curr Opin Plant Biol 2006, 9:274-280.

20. Whitehead IM, Muller BL, Dean C: Industrial use of soybean lipoxygenase for the production of natural green note flavour compounds. Cereal Foods World 1995, 40:193-194.

21. Gigot C, Ongena M, Fauconnier M-L, Wathelet J-P, du Jardin P, Thonart P: The lipoxygenase metabolic pathway in plants: potential for industrial production of natural green leaf volatiles. Biotechnol Agron soc Environ 2010, 14:451-460.

22. Lam HS, Proctor A: Milled rice oxidation volatiles and odour development. J Food Sci 2002, 68:2676-2681.

23. Kuroda H, Furusho S, Maeba H, Takashio M: Characterization of factors involved in the production of 2(E)-nonenal during mashing. Biosci Biotechnol Biochem 2003, 67:691-697.

24. Schieberle P, Ofner S, Grosh W: Evaluation of potent odorants in cucumbers and muskmelons by aroma extract dilution analysis. J Food Sci 1990, 55:193-195.

25. Palma-Harris C, McFeeters RF, Fleming HP: Fresh cucumber flavour in refrigerated pickles: comparison of sensory and instrumental analysis. $J$ Agric Food Chem 2002, 50:4875-4877.

26. Singh TK, Drake MA, Cadwallader KR: Flavour of Cheddar cheese: a chemical and sensory perspective. CRFSFS 2003, 2:139-162.

27. Hubert J, Múnzbergová Z, Nesvorná M, Poltronieri P, Santino A: Acaricidal effects of natural six-carbon and nine-carbon aldehydes on storedproduct mites. Exp Appl Acarology 2008, 44:315-321.

28. Schrader J, Etschmann MMW, Sell D, Hilmer J-M, Rabenhorst J: Applied biocatalysis for the synthesis of natural flavour compounds - current industrial processes and future prospects. Biotechnol Lett 2004, 26:463-472.

29. Dubal SA, Tilkari YP, Momin SA, Borkar IV: Biotechnological routes in flavour industries. Advanced Biotech 2008, 20-31.

30. Muller BL, Dean C, Whitehead IM: The industrial use of plant enzymes for the production of natural 'green note' flavour compounds. Edited by: Étiévant P, Schreier P. Paris INRA; 339-344, Bioflavour 95, Dijon (France) February 14-17.

31. Morrison RT, Boyd RN: Organic chemistry. Allyn and Bacon, Boston, 41983.

32. Hayes DG: The catalytic activity of lipases toward hydroxy fatty acids - a review. JAOCS 1996, 73:543-549.

33. Gopinath M, Vijayakumar L, Dhanasekar R, Viruthagiri T: Microbial biosynthesis of $\gamma$-decalactone and its application - a review. Global J Biotechnol Biochem 2008, 3:60-68.

34. Cardillo R, Fronza G, Fuganti C, Grasselli P, Mele A, Pizzi D: Stereochemistry of the microbial generation of $\delta$-decanolide, $\gamma$-dodecanolide, and $\gamma$ nonanolide from C18 13-hydroxy, C18 10-hydroxy, and C19 14-hydroxy unsaturated fatty acids. J Org Chem 1991, 56:5237-5239.

35. Ranka AL: Functionalized hydroxyl fatty acid polymer surface active agents and methods of making same. 2001, 59, Patent US 6242559 B1.

36. Odian GG: Principles of polymerization. John Wiley \& Sons, Inc. New York, 42004.

37. Gardner HW: Lipoxygenase as a versatile biocatalyst. JAOCS 1996, 73:1347-1357.

38. Elshof MBW, Veldink GA, Vliegenthart JFG: Biocatalytic hydroxylation of linoleic acid in a double-fed batch system with lipoxygenase and cysteine. Fett/Lipid 1998, 100:246-251.

39. Simpson TD, Gardner HW: Conversion of 13(S)-hydroperoxy-9(Z),11(E)octadecadienoic acid to the corresponding hydroxy fatty acid by $\mathrm{KOH}$ : a kinetic study. Lipids 1993, 28:325-330.

40. Heitz T, Bergey DR, Ryan CA: A gene encoding a chloroplast-targeted lipoxygenase in tomato leaves is transiently induced by wounding, systemin, and methyl jasmonate. Plant Physiol 1997, 114:1085-1093.

41. Marillonnet S, Giritch A, Gils M, Kandzia R, Klimyuk V, Gleba Y: In planta engineering of viral RNA replicons: efficient assembly by recombination of DNA modules delivered by Agrobacterium. Proc Natl Acad Sci USA 2004, 101:6852-6857.
42. Marillonnet S, Thoeringer C, Kandzia R, Klimyuk V, Gleba Y: Systemic Agrobacterium tumefaciens-mediated transfection of viral replicons for efficient transient expression in plants. Nat Biotechnol 2005, 23:718-723.

43. Véronési $C$, Rickauer $M$, Fournier J, Pouénat $M-L$, Esquerré-Tugayé $M-T$ : Lipoxygenase gene expression in the tobacco-Phytophthora parasitica nicotianae interaction. Plant Physiol 1996, 112:997-1004.

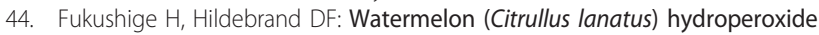
lyase greatly increase $C_{6}$ aldehyde formation in transgenic leaves. J Agric Food Chem 2005, 53:2046-2051.

45. Tijet N, Schneider C, Muller BL, Brash AR: Biogenesis of volatile aldehydes from fatty acid hydroperoxides: molecular cloning of a hydroperoxide layse (CYP74C) with specificity for both the 9- and 13-hydroperoxides of linoleic and linolenic acids. Arch Biochem Biophys 2001, 386:281-289.

46. Fournier J, Pouénat M-L, Richauer M, Rabinovitch-Chable H, Rigaud M, Esquerré-Tugayé M-T: Purification and characterization of an elicitorinduced lipoxygenase in tobacco cell. Plant J 1993, 3:63-70.

47. Ruzicska P, Gombos Z, Farkas GL: Modification of the fatty acid composition of phospholipids during the hypersensitive reaction in tobacco. Virology 1983, 128:60-64.

48. Halitschke R, Baldwin IT: Antisense LOX expression increases herbivore performance by decreasing defense responses and inhibiting growthrelated transcriptional reorganization in Nicotiana attenuata. Plant $J$ 2003, 36:794-807.

49. Noordermeer MA, van der Goot W, van Kooij AJ, Veldsink JW, Veldink GA, Vliegenthart JFG: Development of a biocatalytic process for the production of $\mathrm{C}_{6}$-aldehydes from vegetable oils by soybean lipoxygenase and recombinant hydroperoxide lyase. J Agric Food Chem 2002, 50:4270-4274.

50. Fukushige $H$, Hildebrand DF: A simple and efficient system for green note compound biogenesis by use of certain lipoxygenase and hydroperoxide lyase sources. J Agric Food Chem 2005, 53:6877-6882.

51. Németh ÁS, Márczy JS, Samu Z, Háger-Veress Á, Szajáni B: Biocatalytic production of 2(E)-hexenal from hydrolysed linseed oil. Enzyme Microb Technol 2004, 34:667-672.

52. Rabetafika HN, Gigot C, Fauconnier M-L, Ongena M, Destain J, du Jardin P, Wathelet J-P, Thonart P: Sugar beet leaves as new source of hydroperoxide lyase in a bioprocess producing green-note aldehydes. Biotechnol Lett 2008, 30:1115-1119.

53. Drouet $P$, Thomas D, Legoy MD: Producton of 13(S)-hydroperoxy-9(Z), 11 (E)-octadecadienoic acid using soybean lipoxygenase 1 in a biphasic octane-water system. Tetrahedron Lett 1994, 35:3923-3926.

54. Elshof BMW, Janssen M, Veldink GA, Vliegenthart JFG: Biocatalytic largescale production of $13(S)$-hydroperoxy-9(Z),11(E)-octadecadienoic acid from hydrolysed safflower oil by a crude soybean-flour extract as lipoxygenase source. Recl Trav Chim Pays-Bas 1996, 115:499-504.

55. Fauconnier $M-L$, Marlier M: An efficient procedure for the production of fatty acid hydroperoxides from hydrolyzed flax seed oil and soybean lipoxygenase. Biotechnol Techn 1996, 10:839-844.

56. Höfgen R, Willmitzer L: Storage of competent cells for Agrobacterium transformation. Nucleic Acids Res 1988, 16:9877.

57. Liao Z, Chen M, Guo L, Gong Y, Tang F, Sun X, Tang K: Rapid isolation of high-quality total RNA from Taxus and Ginkgo. Prep Biochem Biotech 2004, 34:209-214.

58. Pfaffl MW: A new mathematical model for relative quantification in realtime RT-PCR. Nucleic Acids Res 2001, 29:2002-2007.

doi:10.1186/1472-6750-11-30

Cite this article as: Huang and Schwab: Cloning and characterization of a 9-lipoxygenase gene induced by pathogen attack from Nicotiana benthamiana for biotechnological application. BMC Biotechnology 2011 11:30. 